\title{
ЯНКОВСКИЙ Д.С., ШИРОБОКОВ В.П., ДЫМЕНТ Г.С. МИКРОБИОМ. - КИЕВ: ФЛП ВЕРЕС О.И., 2017. - 640 с.
}

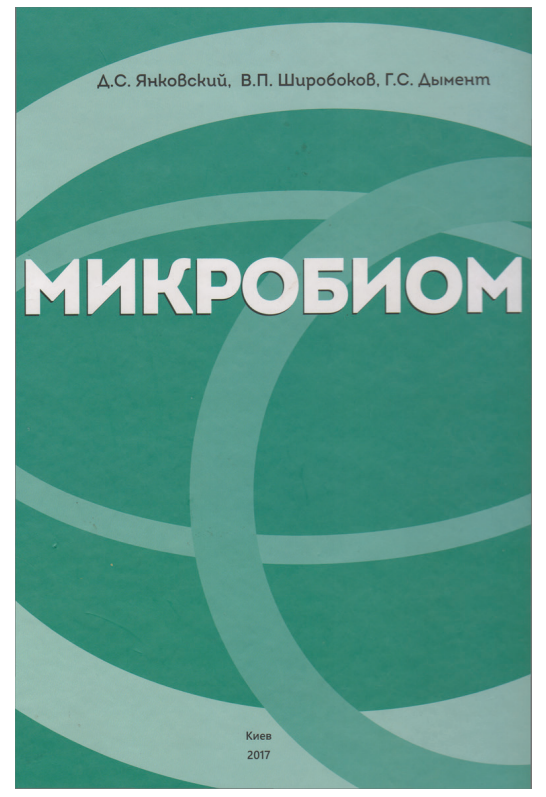

Прорецензована монографрія, на думку авторів, є капітальною працею, в якій наведені основні наукові положення про роль мікробіому з моменту від зародження біосорери, молекулярно-біологічної організації представників мікробного світу, екології мікроорганізмів до мікробіому людини. Вона є завершеною, і зацікавлений читач зможе поповнити свої знання в галузі мікробіому людини. Буде корисною мікробіологам, інфекціоністам, дерматовенерологам, спеціалістам з ЛОР-захворювань, педіатрам, хірургам та іншим лікарям практичної охорони здоров'я.

Ключові слова: мікробіом, рецензія.

Бурхливий розвиток медичної науки і практики охорони здоров'я з особливою очевидністю демонструє важливість і фундаментальне значення мікробіому для людини, тварин і всієї біосфери. Знання про мікробіом набуває особливого значення для медичної науки і практики охорони здоров'я.

Сфрормований у процесі еволюційного (фрілогенезу) та індивідуального (онтогенезу) розвитку симбіоз організму людини, тварин та його мікробної екологічної системи, став нормою і фрормою життя людини і тварин. Кількість мікроорганізмів, що контамінують і колонізують тіло людини, у десятки і сотні разів перевищує кількість власних еукаріотних клітин хазяїна. За цією ознакою, людина і тварини є не просто живим моноорганізмом, а макроорганізмом з надорганною життєздатною мікробною симбіотною системою - екстракорпоральною фрункціональною симбіотною системою. Остання включає сукупність великої кількості мікробіоценозів індивідуального таксономічного складу і популяційного рівня, які знаходяться в певному біотопі людини (шкіри, порожнини рота, носоглотки), інтестинального (шлунка, тонкої та товстої кишки) і респіраторного (трахеї, бронхів) тракту та сечостатевої сфери. Із сучасних позицій нормальну мікробіоту розглядають як сукупність мікробіоценозів, що займають численні екологічні ніші на шкірі й слизових оболонках відкритих порожнин макроорганізму. Мікроорганізми, що фоормують нормальний мікробіом, знаходяться між собою в різноманітних взаємовідношеннях (нейтралізму, конкуренції за поживні субстрати, муталізму, синергізму, коменсалізму та ін.). Нестача або надлишок того чи іншого субстрату або метаболіту, так само, як і зміна популяційного рівня у відповідному біотопі, служить сигналом для адаптаційно-компенсаторних або ж незворотних порушень у відповідній ланці мікроекологічної системи «макроорганізм-мікробіом».

Для дослідження нормальної мікробіоти в теперішній час розроблена велика кількість прямих і непрямих методів і прийомів: мікроскопія (імерсійна, фразово-контрасна, електронна, включаючи скануючу), визначення таксономічного складу і популяційного рівня мікробіоценозів; встановлення провідних мікроекологічних показників екосистеми «макроорганізм-мікробіом», постановка навантажувальних тестів 3 індикаторними мікроорганізмами і хімічними сполуками, вивчення персистуючих у біологічних рідинах людини і тварин певних груп мікробів і наявність їх метаболітів тощо. При аналізі одержаних мікробіологічних досліджень повинні виходити із того, що в будь-якому мікробіоценозі завжди виявляються характерні для біотопу мікроорганізми, хочя їх кількість відносно невелика але чисельно вони є домінуючими.

Серед досягнень у вивчені мікробіому людини і тварин в останні роки слід назвати результати, що засвідчують виражену стабільність, індивідуальну та анатомічну специфрічність таксономічного складу і популяційного рівня мікро- 
біому в окремих екологічних нішах. Накопичені численні дані, які засвідчують, що будь-які мікроорганізми як ті, що живуть вільно, так і ті, що знаходяться в організмі людини і тварин, проводять імобілізований спосіб життя. Це означає, що в природніх умовах більшість мікроорганізмів знаходяться у вигляді фріксованих до різних поверхонь мікроколоній. Адгезувавшись, мікроорганізми продукують екзополісахарідний глікокалекс, який обгортає мікробну клітину та утворює біологічну приепітеліальну плівку, всередині якої проходить ріст і розмноження бактерій, здійснюються міжмікробні взаємостосунки, фрормуються мікроколонії, проявляється фрізіологічна фрункція цих колоній. Тут проходить спільна гармонійна діяльність макроорганізму та його фрізіологічної мікробіоти.

Таким чином, людина, з точки зору мікробіолога та інфекціоніста, є ходячою екосистемою - у людському організмі проживає потужна кількість мікробних клітин, що належать до різних таксономічних груп. В одній людині живе сотня трильйонів бактерій. На одну еукаріотну клітину тіла людини припадає 10-100 бактерійних клітин, на кожен ген людини припадає 100 бактерійних генів. Спільне проживання людини 3 мікроорганізмами формує надзвичайно потужній вплив на морфолого-функціональну активність організму і стан здоров'я індивідуума. Частина вітамінів, ферментів, амінокислот та інших біологічних речовин, необхідних для нормальної життєдіяльності людини, забезпечується персистуючими бактеріями різних таксономічних груп.

Мікробіом людини - це нова ера в мікробіологічних дослідженнях людини, яка здійснюється в міжнародному проекті (Human Microbiome Project - (HMP), метою якого $€$ розшифровка 900 повних геномів мікроорганізмів (найпростіших, бактерій та архей), що складають мікробіом людини. Таким чином, Human Microbiome Project $€$ логічним розвитком проекту Human Genom Project, метою якого $€$ повна розшифровка людського генома. Незважаючи на те, що проект стартував у 1990 р., а перший повний геном людини був опублікований у 2003 р., до цього часу проект незавершений. Залишаються нерозшифрованими деякі фррагменти людської ДНК. Угрупування мікроорганізмів перебуває в тісному взаємозв'язку з організмом людини і вони можуть сприяти покращенню життєдіяльності або ж спричиняти певні захворювання.

Це далеко неповна характеристика мікробіому людини, яка опублікована у великій кількості джерел і не дає повноцінної узагальненої оцінки мікробіому людини. Як і в минулі часи, як в Україні, так і на території країн колишнього СНД, відчувається відсутність літератури з мікробіому людини і тварин. Ця прогалина компенсована виходом у світ капітальної праці відомих мікробіологів Дмитра Станіславовича Янковського, Володимира Павловича Широбокова і Галини Семенівни Димент.
Монографрія чітко структурована. Вона включає зміст, список скорочень, вступ, основний зміст, післямову і список першоджерел.

Основний зміст роботи викладений у двох нерівнозначних за об'ємом частинах.

У першій частині «Мікроби і біосфера» викладені загальнобіологічні аспекти ролі мікроорганізмів у зародженні біосфери на Землі. Представлена молекулярно-біологічна організація прокаріотів (бактерій та архей), еукаріотних мікроорганізмів, найпростіших, наноб, вірусів, віроїдів віроїдоподібних сателітних РНК, плазмід і пріонів. Тут подається характеристика вірусів та їх місце і роль у біоссрері.

Уперше в Україні описуються узагальнені світові наукові положення про природні мікробні угрупування як суперорганізм. Показано, що мікроорганізми $є$ есрективними конструкторами суперорганізмів, а прикладом суперорганізму є колонія. Дається детальна характеристика мікробіоти, що формує біологічну приепітеліальну біоплівку як основного резервуара ендогенної мікробіоти, її фрормування в онтогенезі і роль у колонізаційній резистентності слизових оболонок відкритних порожнин організму людини. Завершується характеристика природних мікробних угрупувань описом взаємовідношень у мікробних екосистемах, вказуючи на те, що унікальна структура і фрізіологічна роль приепітеліальної біоплівки в нормальних умовах забезпечують довічне збереження таксономічного складу індигенної мікробіоти, яка є індивідуальною для кожної людини.

Логічним завершенням першої частини є викладення основних наукових положень екології мікроорганізмів - мікросрлори ґрунту, гідроссрери, повітря та екстремальних систем, а також характеристики мікробіоти тварин і рослинного світу.

Важливим для медичної мікробіології та медичної науки взагалі є друга частина монографії «Мікробіом людини», де викладені сучасні відомості періодичної світової літератури з мікробіому людини, його структурної організації та особливостей локальних мікробіоценозів біотопів травного каналу, сечо-статевої системи, шкіри, респіраторного тракту і кон'юнктиви. Логічним продовженням цього розділу $є$ наступний, в якому детально охарактеризована роль мікробіому людини в забезпеченні фрізіологічного гомеостазу в його організмі, а саме, участь мікробіому в реалізації фрізіологічних механізмів організму, у формуванні колонізаційної резистентності слизових оболонок, метаболічних процесів, біосинтетичній і детокситаційній функції. Логічним у продовженні характеристики мікробіому є розділ, де наведені сучасні етапи і механізми орормування нормального мікробіому в онтогенезі, а також його зміни залежно від віку, характеру харчування, способу життя, екологічної ситуації та ін.

Великим за об'ємом і важливістю за змістом є розділ, присвячений порушенню мікробіому залежно від патоло- 
гічного стану. У ньому описані механізми фрормування дисбактеріозу/дисбіозу при різних патологічних станах, синдромах і захворюваннях, а також взаємодії мікробіому людини зі збудниками інфекційних захворювань. Показаний стан мікробіому в практично здорових дітей раннього віку та зміни його при захворюваннях дитячого віку. Детально описані порушення таксономічного складу і популяційного рівня при метаболічних порушеннях онкологічних процесів, коморбітних станів, при імунопатологічних захворюваннях та інших хворобах людини.

Цікавим і змістовним $є$ розділ «Засоби оздоровлення мікробіому», де наводяться основні наукові положення вчення про пробіотики і мікроорганізми, перспективні для використання в складі пробіотиків, їх використання. Крім того, наведено інші засоби оздоровлення мікробіому людини (пребіотики, синбіотики, продукти функціонального харчування, парапробіотики, ентеросорбенти та ін.).

Остання частина монографії присвячена оздоровленню мікробіому як важливого фактора боротьби з порушенням резистентних до лікарських засобів патогенних та умовно-патогенних бактерій, а також наведені концептуальні погляди авторів монографії на проблему оздоровлення мікробіому.

Логічним є підсумок монографрічного видання, який викладений чітко, послідовно і в лаконічній формі на 5 сторінках.

За підсумками наведений список використаної наукової літератури, який містить 2929 літературних першоджерел, серед яких 91,6 \% - це роботи іноземних авторів, що $є$ свідченням того, що монографрія безпосередньо стосується світової науки.

Книга у цілому є капітальною працею, в якій автори подали основні наукові положення про роль мікробіому 3 моменту від зародження біоссрери, молекулярно-біологічної організації представників мікробного світу, екології мікроорганізмів до мікробіому людини. Вона $€$ завершеною $\mathrm{i}$ зацікавлений читач зможе поповнити свої знання в галузі мікробіому людини. Автори хотіли зробити видання доступним медичному працівнику будь-якого фраху. Вона буде корисною мікробіологам, інфекціоністам, дерматовенерологам, спеціалістам з лОР-захворювань, педіатрам, хірургам та іншим лікарям практичної охорони здоров'я.

У монограсрії змістовно і в доступній формі викладені основні наукові положення мікробіому. Вона добре літературно оформлена, прекрасно ілюстрована малюнками і таблицями, в основному унікальними, легко сприймається читачем.

Автори випустили монографрію російською мовою, тож бажано було б підготувати видання і державною мовою.

\section{YANKOVSKIY D.S., SHYROBOKOV V.P., DYMENT G.S. MICROBIOME. - KYIV: FLP VERES O.I., 2017. - 640 p.}

\author{
I.Y. Sydorchuk, S.Ye. Deineka \\ Bukovyna State Medical University
}

SUMMARY. The author's opinion about reviewed monograph, which is the major work in which the authors presented the basic scientific positions on the role of microbiome from the moment of the biosphere's birth, the molecular biological organization of representatives of the microbial world, the ecology of microorganisms to the human microbiome. It is a completed work and interested reader will be able to refill their knowledge in the field of human's microbiome. It will be useful to microbiologists, infectious diseases doctors, dermatologists, ENT specialists, paediatricians, surgeons and other doctors of practical health care.

Key words: microbiome; review.

\section{Інформація про авторів:}

Сидорчук І.Й. - д. мед. н., професор, почесний профресор науково-дослідного «Інституту мікробіології та імунології імені І.І. Мечникова» НАМН України, професор кафедри мікробіології та вірусології ВДНЗ України «Буковинський державний медичний університет» МОЗ України; e-mail: leonidsyd@gmail.com

Дейнека С.Є. - Д. мед. н., професор, завідувач кафедри мікробіології та вірусології ВДНЗ України «Буковинський державний медичний університет» МОЗ України; e-mail: sd@bsmu.edu.ua

\section{Information about authors:}

Sydorchuk I. - Doctor of Medicine, Professor, Honorary Professor of Research Institute of I. Mechnykov Institute of Microbiology and Immunology of the National Academy of Medical Sciences of Ukraine, Professor of the Department of Microbiology and Virology of Bukovyna State Medical University of the Ministry of Health of Ukraine; e-mail: leonidsyd@gmail. com

Deineka S. - Doctor of Medicine, Professor, the Head of the Department of Microbiology and Virology of Bukovyna State Medical University of the Ministry of Health of Ukraine; e-mail: sd@bsmu.edu.ua

Конорлікт інтересів: немає.

Authors have no conflict of interest to declare.

Отримано 6.06.2018 р. 